\title{
Evaluasi Sistem Drainase Menggunakan Storm Water Management Model (SWMM) dalam Mencegah Genangan Air di Kota Tarakan
}

\author{
Rahmat Faizal $^{1}$, Noerman Adi Prsetya ${ }^{2}$, Zikri Alstony $^{3}$, Aditya Rahman ${ }^{4}$ \\ ${ }^{1,2,3,4}$ Program Studi Teknik Sipil, Universitas Borneo Tarakan \\ E-mail: ${ }^{1}$ rahmatfaizal27@gmail.com
}

Received 19 September 2019; Reviewed 09 Oktober 2019; Accepted 21 November 2019

Journal Homepage: http://jurnal.borneo.ac.id/index.php/borneoengineering

\begin{abstract}
Tarakan City experiences problems with standing water during the rainy season, especially in the west Tarakan sub-district which is the center of Tarakan. This puddle not only submerged settlements and offices but also shops and access roads that caused considerable economic losses. An evaluation was carried out by using the Storm Water Management Model (SWMM). SWMM is a rainfall-runoff simulation model used for simulating the quantity and quality of surface runoff from urban areas. Based on the evaluation using SWMM software, the drainage system in Tarakan, especially in Jalan Mulwarman has several inundated channels, namely channels 2, 3, 4, 5, 6, 7, $11,12,13,14$. This is influenced by the dimensions of the drainage channel that cannot accommodate existing water runoff and sediment thickness that covers the drainage channels so that the capacity is reduced, if it rains it will cause puddles at several points in Tarakan City. In order to deal with these puddles, it is necessary to change the dimensions of the channel and routinely dredge sediments that cover the drainage channels.
\end{abstract}

Keywords: SWMM, Drainage, Evaluation, Sediment.

\begin{abstract}
Abstrak
Kota Tarakan mengalami permasalahan mengenai genangan air pada saat musim hujan, khususnya di daerah kecamatan tarakan barat yang merupakan pusat kota tarakan. Genangan ini bukan hanya merendam pemukiman dan perkantoran tetapi juga pertokoan dan akses jalan yang menimbulkan kerugian ekonomi yang cukup besar. Dengan adanya permasalahan ini dilakukan evaluasi dengan menggunakan Storm Water Management Model (SWMM). SWMM merupakan model simulasi hujan-aliran (rainfall-runoff) yang digunakan untuk mensimulasikan kuantitas maupun kualitas limpasan permukaan dari daerah perkotaan. Berdasarkan evaluasi menggunakan software SWMM diperoleh sistem drainase di Torakan terutama di Jalan Mulwarman terdapat beberapa saluran yang tergenang yaitu pada saluran 2, 3, 4, 5, 6, 7, 11, 12, 13, 14. Hal ini dipengaruhi oleh dimensi saluran drainsae tidak dapat menampung limpasan air yang ada serta tebalnya endapan sedimen yang menutupi saluran drainase sehingga daya tampung berkurang, akibatnya jika terjadi hujan maka akan menimbulkan genangan air di beberapa titik di Kota Tarakan. Sehingga untuk mengatasi genangan air tersebut perlu dilakukan perubahan dimensi saluran dan rutin melakukan pengerukan endapan sedimen yang menutupi saluran drainase.
\end{abstract}

Kata kunci: SWMM, Drainase, Evaluasi, Sedimen 


\section{Pendahuluan}

Kota tarakan berada pada sebuah pulau kecil dengan luas wilayah $\pm 250,80 \mathrm{~km}^{2}$, yang secara administratif berada dalam wilayah provinsi kalimantan utara yang merupakan provinsi termuda di indonesia. Secara geografis kota tarakan merupakan daerah yang cukup strategis karena merupakan gerbang masuk ke wilayah kalimantan utara sekaligus sebagai pusat perdagangan, industri dan jasa. Letaknya yang strategis inilah yang membuat Kota Tarakan merupakan kota/kabupaten dengan pertumbuhan ekonomi dan tingkat kepadatan penduduk tertinggi diantara lima kabupatan lainnya.

Hampir setiap tahun kota tarakan mengalami permasalahan mengenai genangan air pada saat musim hujan, khususnya di daerah kecamatan tarakan barat yang merupakan pusat kota tarakan. Genangan ini bukan hanya merendam pemukiman dan perkantoran tetapi juga pertokoan dan akses jalan yang menimbulkan kerugian ekonomi yang cukup besar.

Tarakan barat memiliki kondisi topografi yang landai dengan kondisi lahan yang kritis akibat dari perubahan tata guna lahan yang berubah menjadi daerah pemukiman dan pertokoan yang padat. Bertambahnya kawasan hunian berikut fasilitasnya menyebabkan pemanfaatan lahan yang semula terbuka dan bersifat lolos air yang berfungsi sebagai daerah resapan, berubah menjadi kawasan tertutup perkerasan dan bersifat kedap air, sehingga mengurangi fungsinya sebagai daerah resapan. Pada saat musim hujan menimbulkan permasalahan tersendiri bagi lingkungan. Dalam kondisi normal seharusnya air hujan sebagian besar masuk ke dalam tanah, sebagian lainnya dialirkan, dan ada yang menguap. Permasalahan muncul ketika air tersebut tidak masuk ke dalam tanah (infiltrasi) dan tidak ada sistem pembuangan yang baik, sehingga akan menjadi limpasan di permukaan tanah, hal itu menyebabkan genangan yang dalam kapasitas lebih besar. Maka, untuk mengatasi hal tersebut perlu adanya suatu sistem untuk mengatur pembuangan kelebihan air yang tidak meresap ke dalam tanah, yang kita kenal dengan sebutan Sistem Drainase.

Sistem penanggulangan banjir yang cepat dan tepat hendaknya segera dirancang untuk mengantisipasi banjir yang sering mengancam. Sebuah model yang telah dikembangkan dan digunakan di Amerika mungkin dapat menjadi salah satu solusi pemecahan masalah yang terjadi. Storm Water Management Model (SWMM) merupakan model yang mampu untuk menganalisa permasalahan kuantitas dan kualitas air yang berkaitan dengan limpasan daerah perkotaan. Storm Water Management dikembangkan oleh EPA (Environmental Protection Agency - US). SWMM tergolong model hujan aliran dinamis yang digunakan untuk simulasi dengan rentang waktu yang menerus atau kejadian banjir sesaat. Model ini paling banyak dikembangkan untuk simulasi proses hidrologi dan hidrolika di wilayah perkotaan. SWMM telah diaplikasikan secara luas untuk pemodelan kuantitas dan kualitas air di wilayah perkotaan Amerika Serikat, Kanada, Eropa dan Australia. Model ini telah digunakan untuk analisa hidrolika yang komplek dalam masalah saluran pembuangan, manajemen jaringan drainase Dengan menggunakan SWMM, kondisi yang terjadi di lapangan dapat dimodelkan dengan memasukkan parameter-parameter yang tercatat pada kondisi sesungguhnya (Rossman, Lewis A, 2010). Hal ini menjadikan program SWMM dapat secara akurat memberikan hasil simulasi relatif sama dengan keadaan di lapangan. Dengan berbagai keunggulan dan belum banyak dikembangkan di Indonesia maka penulis memilih program SWMM untuk digunakan dalam evaluasi Sistem Drainase dalam Mencegah Genangan Air di Kota Tarakan.

\section{Metode Penelitian}

Penelitian ini dilakukan di Jalan Mulawarman, Kecamatan tarakan barat, Kota Tarakan Kalimantan Utara. Pemilihan lokasi ini dilakukan karena setiap terjadi hujan dilokasi tersebut selalu terjadi genangan air yang menimbulkan kerugian ekonomi mengingat jalan tersebut adalah jalan strategis di kota tarakan. 


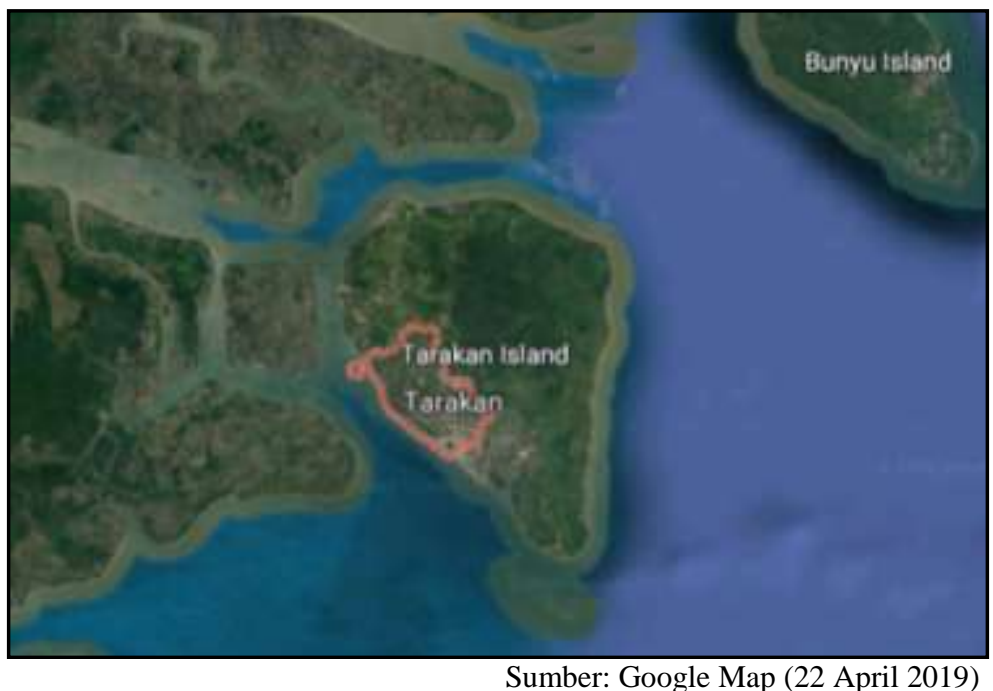

Gambar 3.1. Peta lokasi penelitian

\subsection{Pengumpulan Data}

Data yang digunakan dalam penelitian ini terbagi menjadi dua, yaitu data sekunder dan primer, pengumpulan sekunder berupa data curah hujan harian, data elevasi dan pola aliran, data tata guna lahan yang diperoleh dari dari beberapa instansi maupun dari internet. Adapun data primer berupa dimensi dan panjang saluran drainase yang diperoleh dari lokasi penelitian.

\subsection{Analisis data}

\subsubsection{Periode Ulang dan Analisis Frekuensi}

Hujan rancangan dihitung dengan periode ulang tertentu yang diperoleh dari analisis frekuensi. Periode ulang merupakan waktu dimana hujan dengan besaran waktu tertentu akan disamai atau dilampui sekali dalam jangka waktu tertentu (Bambang Triatmojo, 2009). Tujuan analisis frekuensi mencari hubungan antara besarnya kejadian ekstrim terhadap frekuensi kejadian melalui penerapan distribusi (Suripin, 2004).

Ada 4 metode yang digunakan dalam analisis frekuensi yaitu Distribusi Normal, Distribusi Log Normal, Distribusi Gumbel, dan Distribusi Log Pearson III (Bambang Triatmojo, 2004). Parameter statistik dasar yang digunakan adalah nilai rata-rata (X), standar deviasi (sd), Koefisien Skewness (Cs), Koefisien Variasi (Cv) dan Koefisien Kurtosis (Ck). Menurut Rohmat (2009), metode Green Ampt merupakan fungsi dari parameter hidraulik tanah, yaitu permeabilitas, suction head, dan kelembaban tanah. Parameter-parameter tersebut mempunyai hubungan erat dengan karakteristik fisik tanah.

\subsubsection{Uji Keselarasan Distribusi}

Untuk menguji apakah jenis distribusi yang dipilih sesuai dengan data yang ada yaitu dengan uji Chi-Kuadrat dan Smirnov-Kolmogorov (Bambang Triatmojo, 2009) sebagai berikut:

a. Uji Chi-Kuadrat

Metode uji kesesuaian chi kuadrat dimaksudkan untuk menentukan apakah persamaan distribusi yang telah dipilih dapat mewakili distribusi statistik sampel data yang dianalisis. Uji Chi-Kuadrat mengunakan parameter $X^{2}$ dapat dihitung dengan rumus: 


$$
X^{2}=\sum_{i=1}^{N} \frac{\left(0_{f}-E_{f}\right)^{2}}{E_{i}}
$$

Keterangan:

$X 2$ = Parameter Chi-Kuadrat terhitung

$\mathrm{N}$ = Jumlah Sub Kelompok dalam satu grup

Of $=$ Frekuensi yang terbaca pada kelas yang sama

$\mathrm{Ef}=$ Frekuensi yang diharapkan sesuai dengan pembagian kelas

b. Uji Smirnov-Kolmogorov

Dikenal dengan uji kecocokan non parametrik karena pengujiannya tidak menggunakan fungsi distribusi tertentu, namun dengan memperhatikan kurva dan penggambaran data pada kertas probabilitas. Dari gambar dapat diketahui jarak penyimpangan setiap titik data terhadap kurva. Jarak penyimpangan terbesar merupakan nilai $\Delta$ maks dengan kemungkinan didapat nilai lebih kecil dari nilai $\Delta k r i t i k$, maka jenis distribusi yang dipilih dapat digunakan.

\subsubsection{Intensitas Hujan}

Intensitas hujan adalah tinggi atau kedalaman air per-satuan waktu. Sifat umum intensitas hujan adalah makin singkat hujan berlangsung maka intensitasnya makin tinggi dan makin besar periode ulangnya makin tinggi intensitasnya (M. Rizal Z dkk, 2016). Untuk memperoleh grafik IDF dari data curah hujan harian dilakukan dengan metode Mononobe. Persamaan ini digunakan apabila data hujan jangka pendek tidak tersedia, yang ada hanya data hujan harian.

$$
I=\frac{R_{24}}{24}\left(\frac{24}{t}\right)^{\frac{2}{3}}
$$

Keterangan Rumus :

$\mathrm{I}=$ intensitas hujan $(\mathrm{mm} / \mathrm{jam})$,

$\mathrm{R}_{24}=$ tinggi hujan maksimum harian ( $\left.\mathrm{mm}\right)$,

$\mathrm{t}=$ durasi hujan (jam)

\subsubsection{Model SWMM}

a. Pembagian subcatchment

Langkah awal dalam penggunaan SWMM adalah pembagian subcatchment pada area penelitian. Pembagian tersebut sesuai dengan daerah tangkapan air (DTA) yang ditentukan berdasarkan pada elevasi lahan dan pergerakan limpasan ketika terjadi hujan.

b. Pembuatan Model Jaringan

Pembuatan model jaringan dilakukan berdasarkan sistem jaringan drainase yang ada di lapangan. Model jaringan ini terdiri dari subcatchment, node junction, conduit, outfall node, dan raingauge. Setelah model jaringan selanjutnya dimasukkan semua nilai parameter yang dibutuhkan untuk semua properti tersebut.

c. Simulasi Respon Aliran pada Time Series

Simulasi respon aliran pada time series dilakukan untuk melihat respon debit aliran terhadap waktu berdasarkan sebaran curah hujan. Nilai yang dimasukkan adalah nilai sebaran curah 
hujan terhadap waktu dengan total nilai sesuai dengan curah hujan rancangan hasil dari analisis hidrologi.

d. Simulasi model

Simulasi ini dilakukan setelah model jaringan drainase dan semua parameter berhasil dimasukkan. Simulasi dapat dikatakan berhasil jika continuity error $<10 \%$. Dalam simulasi SWMM besarnya debit banjir dihitung dengan cara memodelkan suatu sistem drainase. Aliran permukaan (Q) terjadi jika air yang ada di dalam tanah mencapai maksimum dan tanah menjadi jenuh. Menurut Rossman (2009), nilai Q dapat dihitung dengan persamaan (4). Selanjutnya limpasan yang terjadi $(Q)$ akan mengalir melalui conduit atau saluran yang ada.

$$
\mathrm{Q}=\mathrm{W} 1 / \mathrm{n}(\mathrm{d}-\mathrm{dp})^{2 / 3} \mathrm{~S}^{1 / 2}
$$

Keterangan :

$\mathrm{Q}=$ debit aliran yang terjadi ( $\mathrm{m} 3 / \mathrm{det})$

$\mathrm{W}=$ lebar subcatchment $(\mathrm{m})$

$\mathrm{n}=$ koefisien kekasaran Manning

$\mathrm{d}=$ kedalaman air $(\mathrm{m})$

$\mathrm{dp}=$ kedalaman air tanah $(\mathrm{m})$

$\mathrm{S}=$ kemiringan subcatchment

e. Output SWMM

Output dari simulasi ini antara lain runoff quantity continuity, flow routing continutiy, highest flow instability indexes, routing time step, subcatchment runoff, node depth, node inflow, node surcharge, node flooding, outfall loading, link flow, dan conduit surcharge yang disajikan dalam laporan statistik simulasi rancangan.

f. Visualiasi hasil

Visualisasi hasil yang ditampilkan berupa jaringan saluran drainase hasil output dari simulasi, profil aliran dari beberapa saluran utama dan yang diketahui tergenang, dan grafik aliran yang terjadi pada saluran.melalui conduit atau saluran yang ada.

\section{Hasil dan Pembahasan}

\subsection{Analisis Hidrologi}

Pada penelitian ini menggunakan data curah hujan jangka pendek harian 10 tahun terakhir yang diperoleh dari stasiun BMKG Kota Tarakan pada tahun 2009 sampai dengan tahun 2018, data curah hujan ini yang dijadikan dasar dalam melakukan Perhitungan intensitas curah hujan. Data curah hujan dapat dilihat pada Tabel 1.

Tabel 3.1 Data Curah Hujan Harian tahun 2009-2018

\begin{tabular}{cccc}
\hline Tahun & Curah Hujan $(\mathbf{m m})$ & Tahun & Curah Hujan $(\mathbf{m m})$ \\
\hline 2009 & 100,3 & 2014 & 117,4 \\
2010 & 137,9 & 2015 & 103,6 \\
2011 & 114,6 & 2016 & 137,0 \\
2012 & 137,5 & 2017 & 133,6 \\
2013 & 117,4 & 2018 & 331,3 \\
\hline
\end{tabular}

\subsubsection{Analisis Frekuensi Curah Hujan}

Dalam analisi frekuensi diperlukan data-data statistik dasar sebagai syarat dalam menentukan jenis distribusi yang akan digunakan. Berdasarkan data curah hujan yang ada diperoleh statistk dasar yang dapat dihat pada tabel 4.2 


\begin{tabular}{|c|c|}
\hline Parameter Statistik & Hasil \\
\hline Nilai Rerata (x) & 143,06 \\
\hline Standar deviasi (Sd) & 67,60 \\
\hline Koefisien skewnes (Cs) & 2,910 \\
\hline Koefisien kurtosis (Ck) & 8,858 \\
\hline Koefisien variasi $(\mathrm{Cv})$ & 0,473 \\
\hline Nilai Tengah & 125,5 \\
\hline
\end{tabular}

Setelah diperoleh data-data perhitungan statisti dasar berupa nilai rata-rata $(\bar{x})$, Standar deviasi $(\mathrm{SD})$, koefisien variasi $(\mathrm{Cv})$, koefisien skewness $(\mathrm{Cs})$, koefisien kurtosis $(\mathrm{Ck})$ langkah seanjutnya adalah dengan menentukan distribusi yang akan digunakan. Distribusi yang sering digunakan dalam melakukan analsis frekuensi hujan adalah distribusi Normal, distribusi Log-normal, distribusi gumbel, dan distribusi log pearson III. Penentuan jenis distribusi dilakukan dengan mencocokkan parameter statistik dasar dengan menghitung parameter-parameter pada tabel 4.2 kemudian dibandingkan dengan syarat masing-masing jenis distribusi yang hasilnya dapat dilihat pada tabel 4.3.

\subsection{Hasil Perhitungan Parameter Statistik Dasar untuk Penentuan Pola}

Distribusi Hujan

\begin{tabular}{|c|c|c|c|c|c|}
\hline No & Distribusi & Data & Persyaratan & $\begin{array}{c}\text { Hasil } \\
\text { Hitungan }\end{array}$ & Ket \\
\hline \multirow[t]{2}{*}{1} & Normal & $\mathrm{Cv}=0,473$ & $\mathrm{Cs} \approx 0$ & 2,910 & Kurang \\
\hline & & & $\mathrm{Ck} \approx 3$ & 8,858 & Kurang \\
\hline \multirow[t]{2}{*}{2} & Log Normal & & $\mathrm{Cs}=\mathrm{Cv}^{3}+3 \mathrm{Cv}$ & 1,523 & Kurang \\
\hline & & & $\begin{array}{l}\mathrm{Ck}=\mathrm{Cv}^{8}+6 \\
\mathrm{Cv}^{6}+15 \mathrm{Cv}^{4}+16 \mathrm{Cv}^{2}+3\end{array}$ & 7,390 & Kurang \\
\hline \multirow[t]{2}{*}{3} & Gumbel & & $\mathrm{Cs}=1,14$ & 2,910 & Kurang \\
\hline & & & $\mathrm{Ck}=5,4$ & 8,858 & Kurang \\
\hline \multirow[t]{2}{*}{4} & Log Pearson & & $\mathrm{Cs} \neq 0$ & 2,910 & Mendekati \\
\hline & III & & $\mathrm{Cv} \approx 0,3$ & 0,473 & Mendekati \\
\hline
\end{tabular}

Pada tabel 4.3 diperoleh bahwa parameter statistik dari perbandingan untuk distribusi Normal, Log Normal dan distribusi Gumbel tidak ada yang mendekati persyaratan. Sedangkan, Namun untuk distribusi Log Pearson III dengan persyarataan Cs $\neq 0$ dimana nilai Cs sebesar 2,910. Setelah dibandingkan nilai Cs tidak menekati dengan 0 , hal ini sesuai dengan persyaratan. Sedangkan untuk persyaratan kedua yaitu $\mathrm{Cv} \approx 0$ didapatkan bahwa nilai $\mathrm{Cv}$ sebesar 0,473 dan nilai tersebut mendekati 0,3. Maka dari kedua persyaratan, dapat diperoleh kesimpulan bahwa pola distribusi hujan yang digunakan adalah distribusi Log Person III.

Pengujian distribusi hujan dengan menggunakan distribusi Log-Person III diperoleh koefisien skewness (Cs) 2,456 sehingga nilai $\mathrm{K}$ dapat diperoleh dengan mengggunakan tabel persamaan Log Pearson III Per 5 Tahun dengan nilai 0,518. Sehingga dapat diperoleh hujan rancagan distribusi log-pearson III yang dapat dilihat pada Tabel 4.4

Berdasarkan Departemen Pekerjaan Umum (2014) mengenai Tata Cara Perencanaan Sistem Drainase Perkotaan. Dalam menentukan periode kala ulang curah hujan berdasarkan tipologi kota ,dimana kota Tarakan merupakan kota sedang dengan tangkapan air lebih lebih dari $500 \mathrm{Ha}$, dengan demikian periode kala ulang yang digunakan dalam merencakan drainase adalah kala ulang 5-10 tahun. 
Tabel 3.4 Perhitungan hujan rancagan distribusi log-pearson III

\begin{tabular}{cccc}
\hline $\mathbf{T}$ (tahun) & $\mathbf{K}$ & LOG XT $(\mathbf{m m})$ & XT (mm) \\
\hline 2 & $-0,36$ & 2,075 & 118,759 \\
5 & 0,518 & 2,204 & 159,852 \\
10 & 1,25 & 2,311 & 204,791 \\
25 & 2,262 & 2,460 & 288,442 \\
50 & 3,048 & 2,576 & 376,347 \\
\hline
\end{tabular}

\subsubsection{Analisis Intensitas Hujan}

Untuk analisis intensitas hujan diperlukan distribusi intensitas hujan selama 360 menit. Dengan durasi mulai dari 5 menit sampai 360 menit dan dengan periode ulang 1 tahun sampai 20 tahun. Tabel distribusi intensitas hujan dapat dilihat pada tabel 4.5

Tabel 4.5. Distribusi intensitas Hujan

\begin{tabular}{cccccc}
\hline \multirow{2}{*}{$\begin{array}{c}\text { Periode Ulang (Tahun) } \\
\text { (Jam) }\end{array}$} & $\mathbf{2}$ & $\mathbf{5}$ & $\mathbf{1 0}$ & $\mathbf{2 5}$ & $\mathbf{5 0}$ \\
\cline { 2 - 6 } & 221,75 & 298,48 & 382,40 & 538,60 & 702,74 \\
0,08 & 134,16 & 180,58 & 231,35 & 325,85 & 425,16 \\
0,17 & 103,74 & 139,65 & 178,90 & 251,98 & 328,77 \\
0,25 & 65,36 & 87,97 & 112,70 & 158,74 & 207,112 \\
0,5 & 49,88 & 67,13 & 86,01 & 121,14 & 158,06 \\
0,75 & 41,17 & 55,42 & 70,99 & 99,99 & 130,47 \\
1 & 25,94 & 34,91 & 44,73 & 62,99 & 82,19 \\
2 & 19,79 & 26,64 & 34,13 & 48,07 & 62,73 \\
3 & 16,34 & 21,99 & 28,18 & 39,68 & 51,78 \\
4 & 14,08 & 18,95 & 24,28 & 34,20 & 44,62 \\
5 & 12,46 & 16,78 & 21,50 & 30,28 & 39,51 \\
6 & & & & &
\end{tabular}

Pada tabel 4.5 terlihat semakin singkat hujan yang berlansung maka semakin tinggi pula intensitas hujan yang terjadi, begitupun sebalikanya semakin lama hujan berlansung maka semakin rendah pula intensitas hujan yang yang terjadi, data hujan ini akan dijadikan sebagai inputan pada software Storm Water Management Model (SWMM) yang digunakan dalam mengevaluasi sistem drainase yang ada.

\subsection{Analisis Drainase Dengan EPA SWMM 5.1}

Dalam melakukan analisis drainase dilakukan menggunakan software EPA SWMM 5.1 dengan membagi subcatcment area menjadi 15 subcatcment, 16 Junction, 5 outfall, dan 16 conduit. 


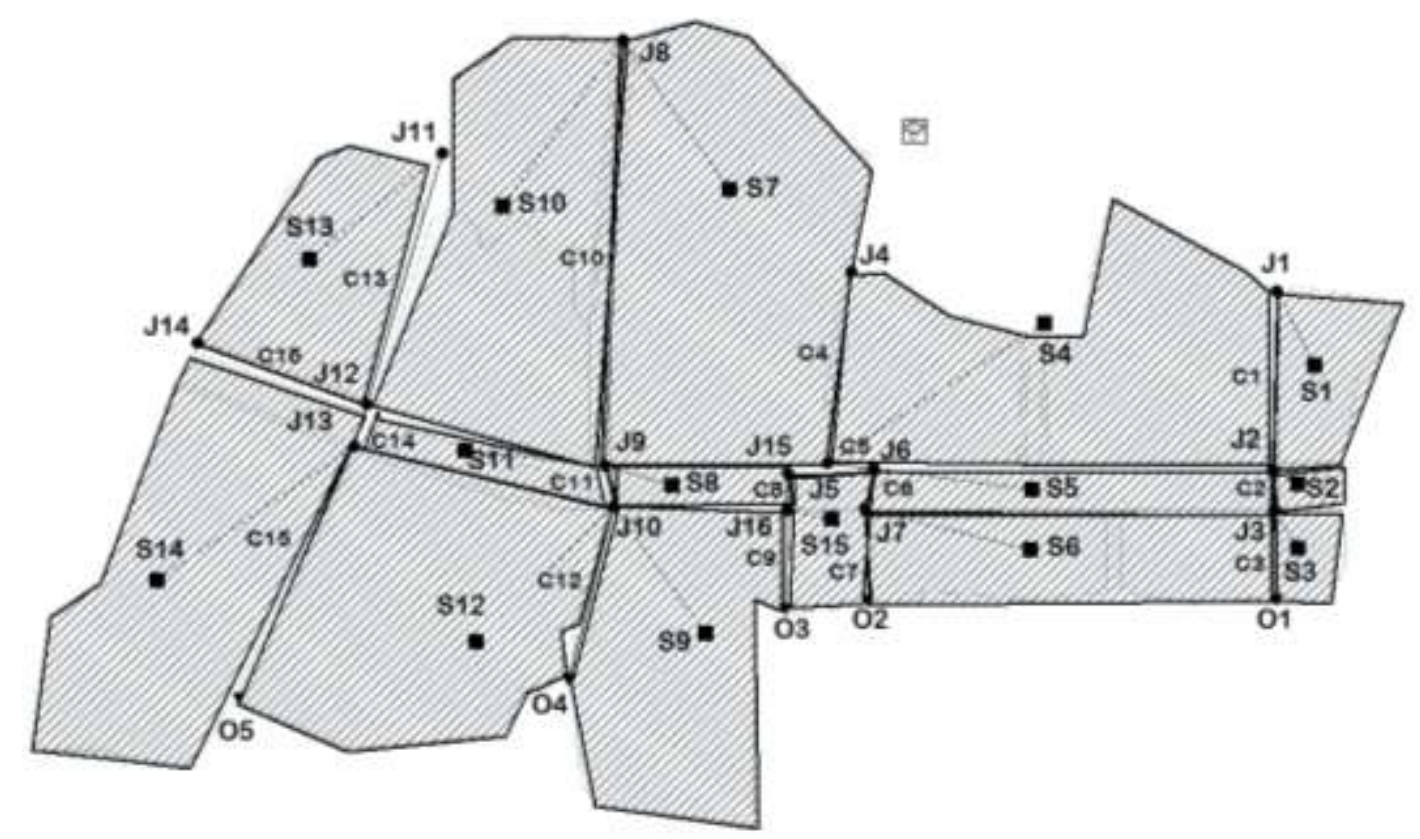

Gambar 1. Sistem jaringan drainase jalan Mulawarman

\subsubsection{Kondisi Topografi}

Kondisi topografi disetiap juction di daerah penelitian dapat dilihat pada Tabel 3.6.

Tabel 3.6. Data dan elevasi disetiap node dan outfall

\begin{tabular}{cccccc}
\hline Node & $\begin{array}{c}\text { Elevasi } \\
(\mathbf{m})\end{array}$ & $\begin{array}{c}\text { Max Dept } \\
(\mathbf{m})\end{array}$ & Node & $\begin{array}{c}\text { Elevasi } \\
(\mathbf{m})\end{array}$ & $\begin{array}{c}\text { Max dept } \\
(\mathbf{m})\end{array}$ \\
\hline J1 & 9,14 & 1,19 & J9 & 4,57 & 1,19 \\
J2 & 8,23 & 1,80 & J10 & 4,51 & 1,13 \\
J3 & 8.17 & 1,80 & J11 & 5,49 & 2,1 \\
J4 & 7,62 & 1,01 & J12 & 5,36 & 2,1 \\
J5 & 5,27 & 1,19 & J13 & 5,30 & 2,1 \\
J6 & 5,18 & 1,19 & J14 & 5,79 & 1,19 \\
J7 & 5,29 & 1,19 & J15 & 5,24 & 1,19 \\
J8 & 4,88 & 1,19 & J16 & 4,97 & 1,19 \\
O1 & 7,62 & - & O4 & 4,28 & - \\
O2 & 4,94 & - & O5 & 5,09 & - \\
O3 & 4,88 & - & & & \\
\hline
\end{tabular}

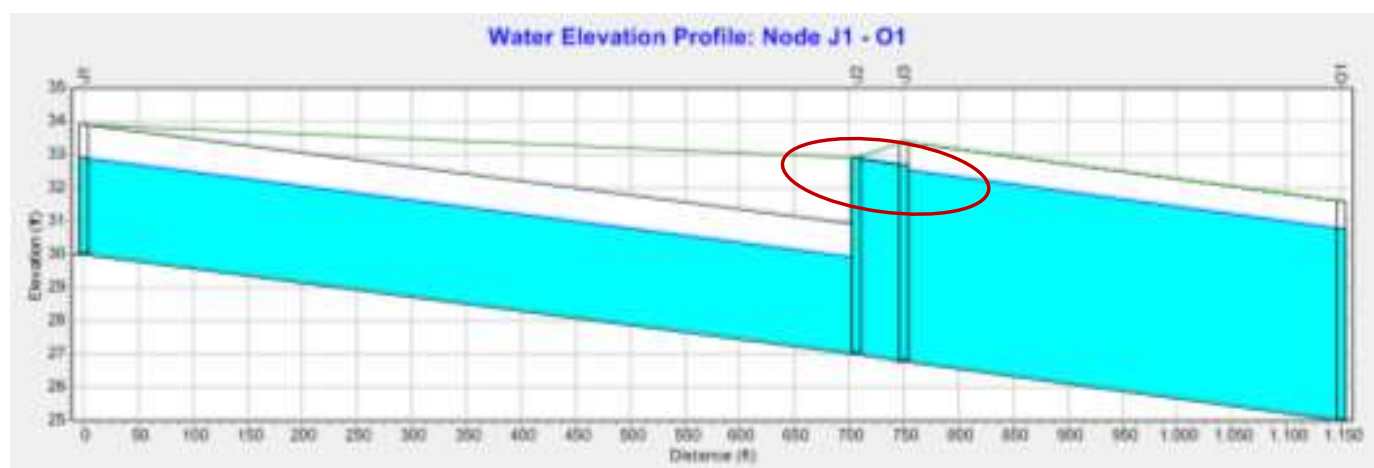

Gambar 2. Long section J1-J2-O1 kala ulang 5 tahun 
Gambar 2. Menunjukkan sistem drainase yang berada disamping masjid darul faizim menunjukkan adanya limpasan yang terjadi pada saluran yang memotong jalan terjadi dikarenakan kapasitas saluran yang berbentuk circular tidak dapat menampung debit air akibat hujan, hal ini juga diperparah dengan ketebalan sedimen yang menutupi disepanjang saluran. Sehingga perlu dilakukan perubahan dimensi saluran terutama pada saluran circular yang memotong jalan.

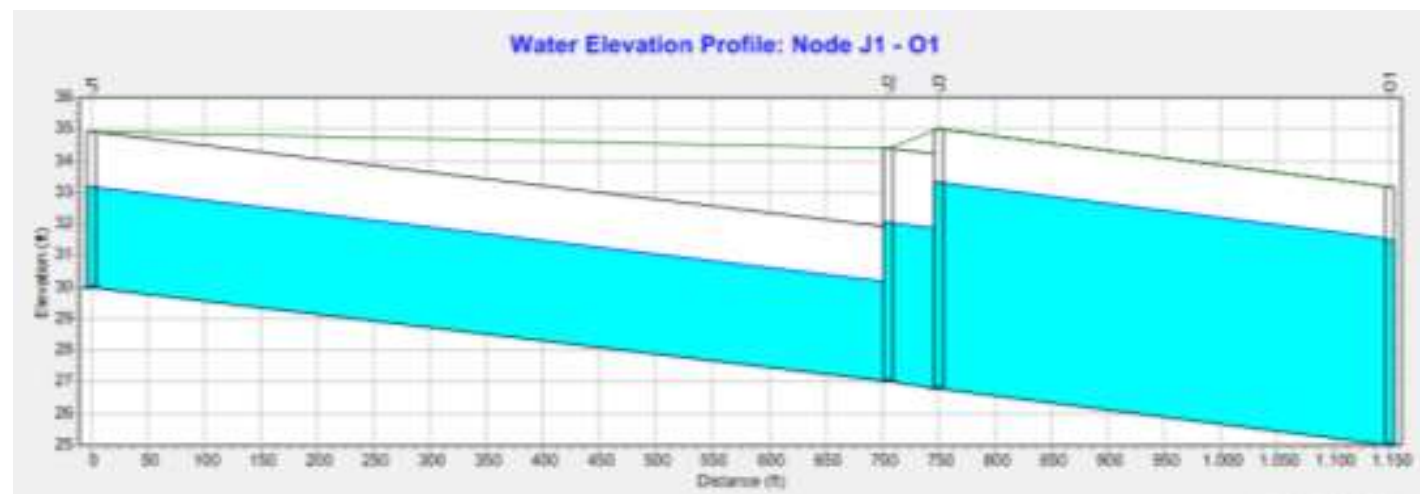

Gambar 3. Long section J1-J2-O1 kala ulang 5 tahun setelah perubahan dimensi

Pada gambar 3 terlihat bahwa setelah dilakukan perubahan dimensi saluran dapat menampung limpasan air yang ada. Perubahan dimensi dapat dilakukan dengan melakukan penambahan kedalaman saluran, pada conduit 1 kedalaman awalnya $1,19 \mathrm{~m}$ dirubah menjadi 1,5 m, untuk conduit 2 berupa saluran circular memiliki dimensi yang terlalu kecil dengan diameter dalam menerima air limpasan sehingga perlu dilakukan penambahan dimensi saluran circular, pada conduit 3 perlu dilakukan penambahan kedalaman dari yang sebelumnya 2 m menjadi $2,5 \mathrm{~m}$. Penambahan dimensi dilakukan hanya pada kedalaman dikarenakan samping kiri kanan saluran berupa bangunan permanen sehingga tidak memungkinkan dilakukan pelebaran saluran.

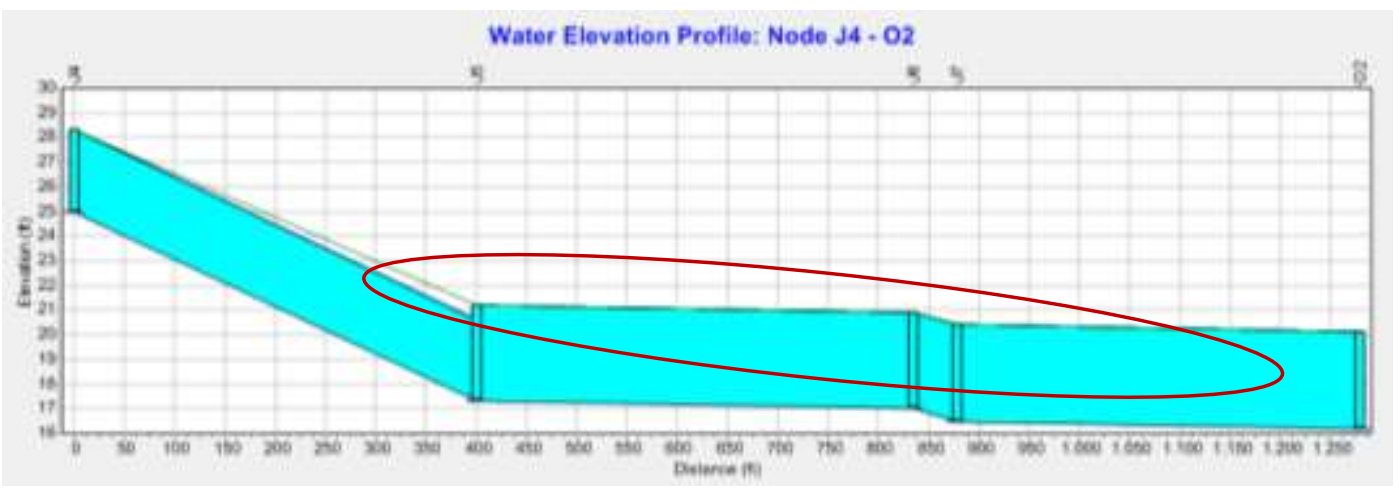

Gambar 4. Long section J4-J5- J6-J7-O1 kala ulang 5 tahun

Pada gambar 4 adalah sistem drinase yang berada di jalan nusa indah hingga drainase di samping toko roti flo, terlihat adanya limpasan air yang tidak dapat tertampung oleh drainase hal ini diakibatkan oleh adanya belokan drainsae dan dimensi yang tidak cukup dalam mengalirkan limpasan air, selain itu juga dipengaruhi kondisi topografi yang landai. Oleh karena itu genangan air terparah sering terjadi di lokasi ini tiap turun hujan. 


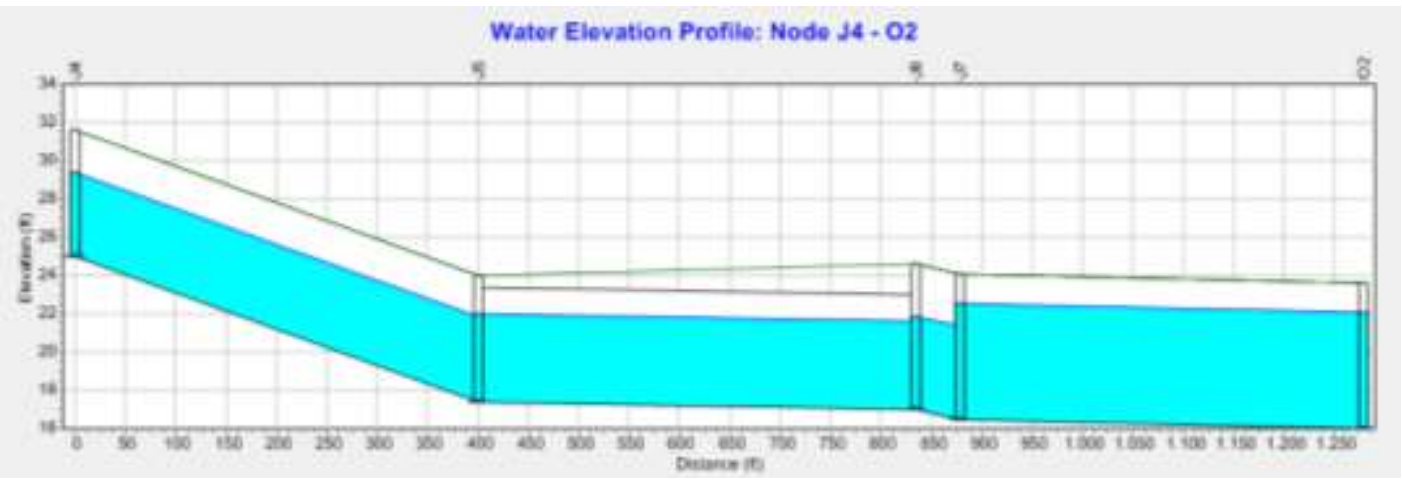

Gambar 5. Long section J4-J5- J6-J7-O1 kala ulang 5 tahun setelah perubahan dimensi

Pada gambar 4 adalah profil Long section J4-J5- J6-J7-O1 kala ulang 5 tahun setelah perubahan dimensi, perubahan dimensi juga hanya dilakukan pada kedalaman hal ini dikarenkan saluran berada pada wilayah yang padat. Pada conduit 4 atau saluran yang menghubungkan junction 4 junction 5 perlu dilakukan penambahan kedalaman menjadi 2 meter yang sebelumnya hanya 1 meter, begitupun dengan lebar saluran dari hanya $0,75 \mathrm{~m}$ menjadi $1 \mathrm{~m}$. Untuk connduit 5 yang menghubungkan junction 5 dan junction 6 dilakukan oenambahan kedalaman dari 1 m menjadi $2 \mathrm{~m}$ sehingga saluran dapat menampung limpasan yang ada. Pada conduit 6 dilakukan merupakan saluran jenis circular dengan kedalaman 2,5 yang sebelumnya hanya $1 \mathrm{~m}$. Pada conduit 7 dilakukan panambahan kedalaman dari $1 \mathrm{~m}$ menjadi 2,5 meter, dengan penambahan kedalaman section J4J5- J6-J7-O1 maka saluran dapat mengalirkan limpasan air yang ada.

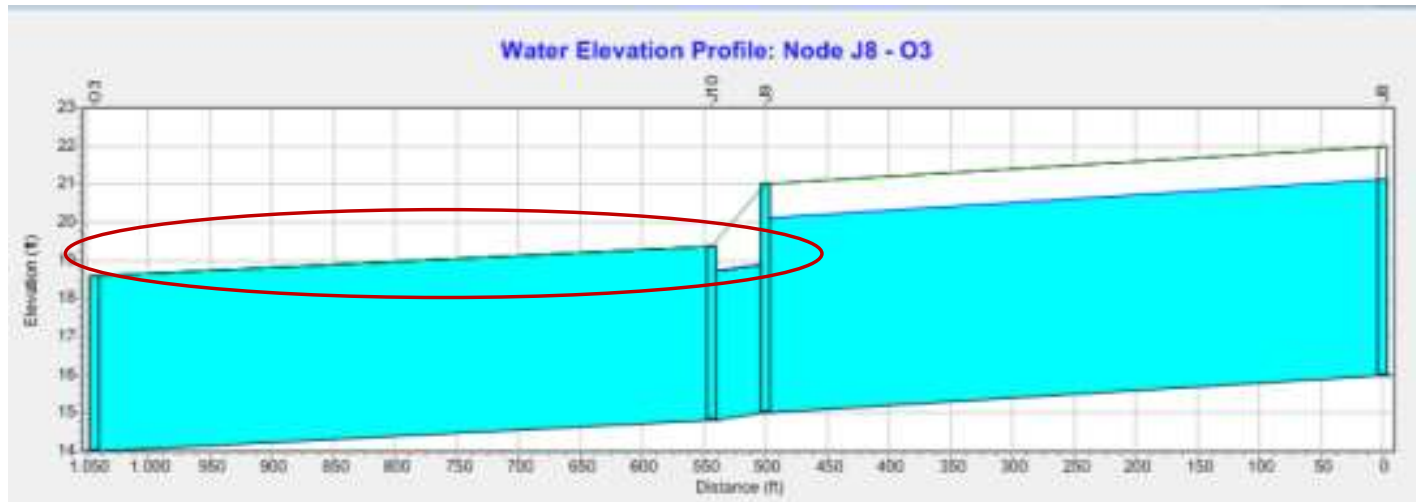

Gambar 6. Long section J8-J9- J10-O3 kala ulang 5 tahun

Pada gambar 6 terlihat pada conduit 11 dan conduit 12 tidak dapat menampung limpasan air dari saluran yang berasal dari perumnas hal ini disebabkan dimensi saluran yang kecil dan juga diperparah tebalnya sedimen yang menutupi conduit 11 dan conduit 12 . Oleh karena itu perlu dilakukan perubahan dimensi dan pengerukan sedimen pada kedua saluran tersebut limpasan air dapat mengalir dengan lancar seperti yang ditunjukkan pada gambar 7. Perubahan dimensi dilakukan pada conduit 11 dengan menambah kedalaman menjadi $2,5 \mathrm{~m}$ yang sebelunya hanya $1 \mathrm{~m}$ dan pada conduit 12 dengan menambah kedalaman yang sebelumnya hanya $1,5 \mathrm{~m}$ menjadi 2,5 meter sehingga terlihat pada gambar 7 air dapat mengalir dn debit air pada conduit 10 dapat terurai. 


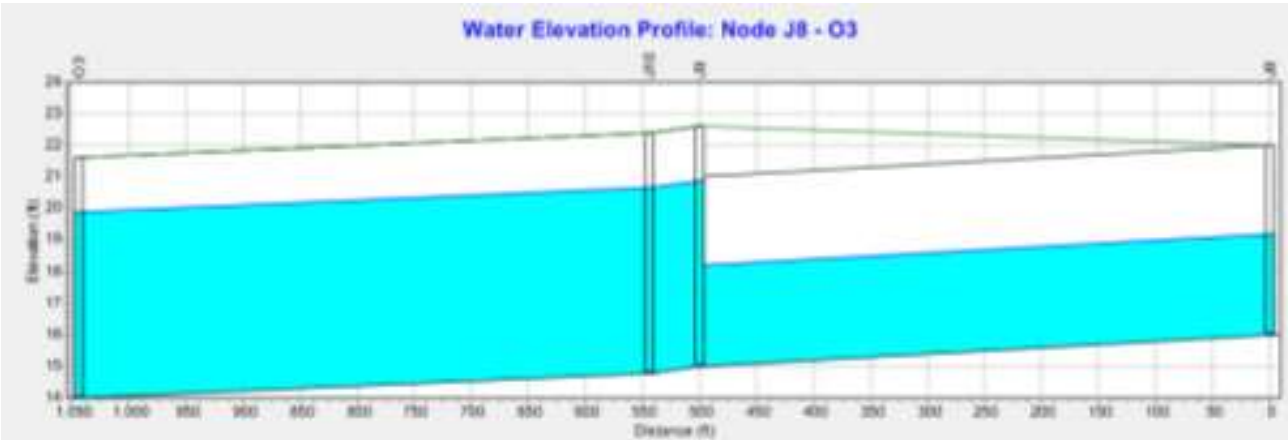

Gambar 7. Long section J8-J9- J10-O3 kala ulang 5 tahun setelah perubahan dimensi

Pada gambar 8 merupakan profil drainase di jalan mulawarman gang celebes hingga jalan hasanuddin. Telihat dan saluran circular yang memotong jalan tidak dapat menampung limpasan air yang ada hal ini dikarenakan dimensi saluran yang kecil sehingga juga berpengaruh terhadap volume air di saluran drainase di gang celebes. Oleh karena itu perlu dilakukan perubahan dimensi sehingga limpasan air yang ada dapat mengalir.

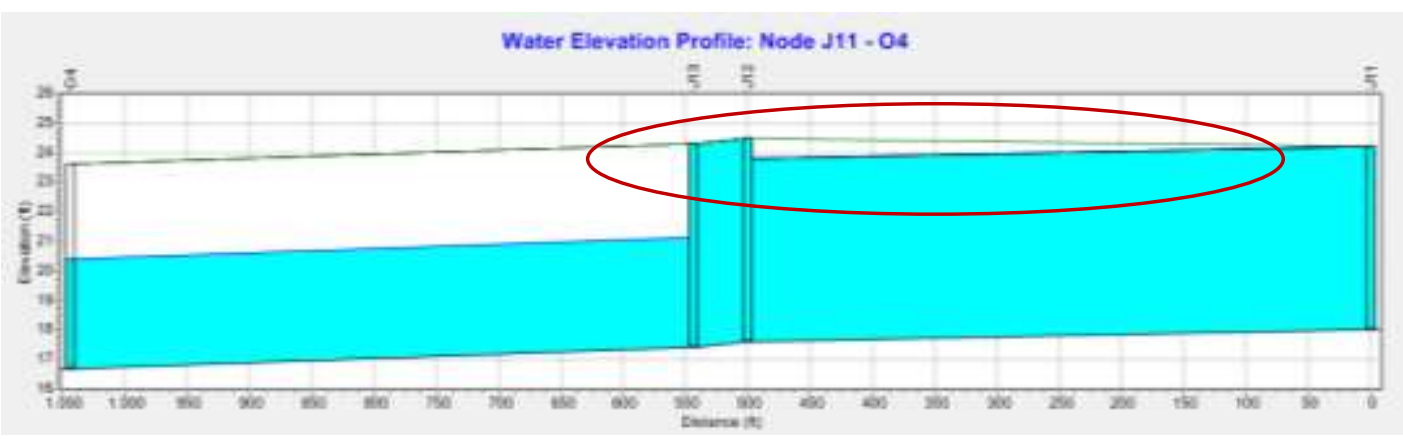

Gambar 8. Long section J11-J12- J13-O4 kala ulang 5 tahun

Gambar 9 merupakan Long section J11-J12- J13-O4 kala ulang 5 tahun setelah dilakukan perubahan dimensi. Pada conduit 13 dilakukan penambahan kedalaman saluran menjadi $3 \mathrm{~m}$ dari sebelumnya hanya $2 \mathrm{~m}$ selain itu juga dilakukan penambahan lebar salurn dari 2,5 m menjadi $3 \mathrm{~m}$. Untuk saluran circular yang memotong jalan dilakukan penambahan kedalaman menjadi 3 dari sebelumnya hanya 2 meter. Pada conduit 15 tidak dilakukan perubahan dimensi karena saluran dianggap cukup mengalirkan limpasan air dari conduit 13 dan conduit 14.

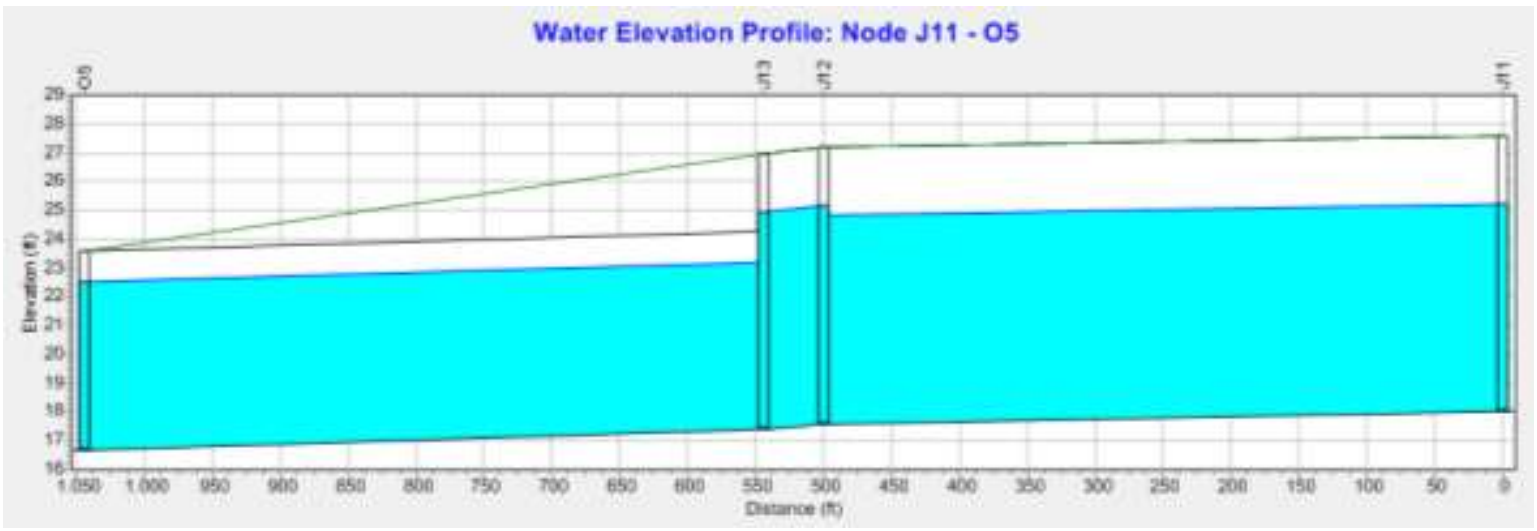

Gambar 9. Long section J11-J12- J13-O4 kala ulang 5 tahun setelah perubahan dimensi 


\section{Kesimpulan}

Sistem drainase ditarakan terutama di jalan mulwarman sudah tidak dapat lagi menampung limpasan yang ada hal ini dipengaruhi dimensi saluran dan tebalnya endapan sedimen yang menutupi saluran drainase sehingga daya tampung berkurang akibatnya jika terjadi hujan maka akan menimbulkan genangan air di beberapa titik dikota tarakan. Dalam mengatasi genangan air di Kota Tarakan perlu dilakukan perubahan dimensi saluran dan melakukan pengerukan endapan sedimen yang menutupi saluran drainase dibeberapa titil

\section{Daftar Pustaka}

Departemen Pekerjaan Umum. 2014. Tata Cara Perencanaan Sistem Drainase Perkotaan. Jakarta: Kementrian Pekerjaan Umum.

Google earth. http://earth.google.com (diakses pada tanggal 22 April 2019)

M Rizal Zarkani, Bambang Sujatmoko, dan Rinaldi. 2016. Analisa Drainase Untuk Penanggulangan Banjir Menggunakan EPA SWMM (Studi Kasus: Perumahan Mutiara Witayu Kecamatan Rumbai Pekanbaru). Jurnal. Pekanbaru: Fakultas Teknik Sipil Jurusan Teknik Sipil, Universitas Riau.

Rohmat, D. 2009. Tipikal Kuantitas Infiltrasi Menurut Karakteristik Lahan (Kajian Empirik di DAS Cimanuk Bagian Hulu). Jurnal Forum Geografi Vol. 23 No. 1. Bandung (ID): Universitas Pendidikan Indonesia

Rossman, Lewis A. 2009. Storm Water Management Model Applications Manual. Cincinnati : National Risk Management Research Laboratory Office Of Research And Development U.S. Environmental Protection Agency

Rossman, Lewis A. 2010. Storm Water Management Model User's Manual Version 5.0. Cincinnati : National Risk Management Research Laboratory Office Of Research And Development U.S. Environmental Protection Agency.

Suripin. 2004. Sistem Drainase Perkotaan yang Berkelanjutan. Yogyakarta : Andi. 